\title{
Justificativas do Congresso Nacional Brasileiro ao Rigor Penal Legislativo: \\ $O$ estabelecimento do \\ populismo penal no Brasil contemporâneo
}

\author{
Luís Wanderley Gazoto \\ Orientador: Profa Dra Maria Stela Grossi Porto
}

Curso: Doutorado de Sociologia

Data da Defesa: 28.04.2010

$[1]$

objeto da presente pesquisa é o populismo penal do poder legislativo brasileiro, após a edição do Código Penal de 1940, mas, principalmente, contemporâneo, analisado por meio das representações sociais ressaltadas no processo da criminalização e, principalmente, nas exposições de motivos dos projetos de lei. Para constatar-se tal fenômeno, foram analisados todos os projetos das leis alteradoras do sistema penal, de 1940 a junho de 2009; todos os projetos de leis da Câmara dos Deputados, de janeiro de 2007 a junho de 2009, bem como do Senado Federal, de janeiro de 2003 a junho de 2009. A pesquisa revelou que 1 . as exposições dos motivos dos projetos de leis quase sempre trazem como argumento a necessidade da repressão, sem, todavia, a apresentação de dados empíricos que possam sustentar suas posições; 2 . é comum o apelo exagerado, puramente retórico, do valor ético-moral da proteção estatal ao interesse em questão, mas sem nenhuma referência a critérios de proporcionalidade; 3. não poucas vezes, os parlamentares deixam expresso que suas preocupações decorrem de leituras de jornais e influência da mídia, em geral; 4. em projetos que envolvem o tema proteção de menores, mulheres, idosos e minorias é prática comum a criação de medidas extrapenais meramente programáticas, mas que, concretamente, aumentam penas e incidências de aplicação de leis penais; tais projetos têm tido como autoras indiretas entidades e associações representativas de interesses desses segmentos sociais; 5 . recentemente, houve uma maior focalização nos temas dos crimes praticados na direção de veículo automotor - mormente quando há embriaguez -, bem como na pedofilia, corrupção e infrações de menores; fatos que sempre ocorreram, mas que tiveram forte presença na mídia dos últimos anos; 6 . as representações, influências e tendências ao rigor 
penal são encontradas, em um mesmo grau de intensidade, na Câmara dos Deputados e no Senado Federal, bem como em todos os principais partidos políticos; 7. diversamente, muitos projetos penalizantes são de autoria de parlamentares oriundos de profissões ligadas à repressão criminal: policiais civis e militares e membros do Ministério Público. De tudo, pode-se extrair a conclusão geral de que o Poder Legislativo brasileiro contemporâneo muitas vezes justifica o maior rigor penal nas representações sociais, na opinião pública e da mídia indicativas da necessidade da repressão penal, porém, tal procedimento, afastado dos demais princípios que regem as sanções penais, vem resultando em penas excessivamente rigorosas, caracterizando um populismo penal legislativo.

Palavras-chave: populismo penal; poder legislativo; criminalização; leis penais; representações sociais; projetos de leis; exposições de motivos; influência da mídia; rigorismo penal; funcionalismo penal; história do direito penal; justificativas da pena; direito penal simbólico. 